\title{
Indicators of sustainable forest management to evaluate the socio-economic functions of coppice in Tuscany, Italy
}

\author{
F. Riccioli ${ }^{\mathrm{a}, *}$, R. Fratini ${ }^{\mathrm{b}}$, E. Marone ${ }^{\mathrm{b}}$, C. Fagarazzi $^{\mathrm{b}}$, M. Calderisi ${ }^{\mathrm{c}}$, G. Brunialti $^{\mathrm{c}}$ \\ ${ }^{a}$ University of Pisa, Department of Veterinary Science, Rural Economics Section, Viale Delle Piagge 2, 56124, Pisa, Italy \\ ${ }^{\mathrm{b}}$ University of Florence, Department of Agricultural, Food and Forestry Systems, Piazzale Delle Cascine 18, 50144, Firenze, Italy \\ ${ }^{\mathrm{c}}$ TerraData Environmetrics, Spin-off of University of Siena, Via Bardelloni 19, Monterotondo Marittimo, GR, Italy
}

\section{A R T I C L E I N F O}

\section{Keywords:}

Sustainable forest management

Ecosystem services

Socioeconomic indicators

Principal component analysis

\begin{abstract}
A B S T R A C T
Due to several ecosystem services provided to the community, the multifunctional management of forests has acquired an important role over the years.

The current Sustainable Forest Management (SFM) guidelines are based on planning programmes which are able to achieve targets from socio-economic and environmental points of view.

In this paper, SFM indicators have been studied and compared to estimate the sustainability of three coppice options, from both an economic and a socio-environmental viewpoint. Each indicator was studied in relationship to the treatment and to the considered areas. The results of the statistical analysis show differences among treatments, and the possible correlations between the indicators. Moreover, by using principal component analysis (PCA), the correlations between the indicators were analysed, while the ways in which they influenced the examined sites were also considered. In particular, specific homogeneous clusters separating the observed sites were observed based on treatment and geographical gradient. Overall, the set of indicators used has proven to be effective when carrying out an evaluation of the existing types of forest management based on the analysis of three fundamental aspects of the SFM.
\end{abstract}

\section{Introduction}

The multifunctional management of forests has acquired, in recent years, increasing importance, influenced by a growing interest in the community in the ecosystem services on offer.

Following a series of international conferences, which began in 1992, in particular, the United Nations Conference on Environment and Development in Rio de Janeiro, the concept of Sustainable Forest Management (SFM) was born. "Sustainable forest management addresses forest degradation and deforestation while increasing direct benefits to people and the environment. At the social level, sustainable forest management contributes to livelihoods, income generation and employment. At the environmental level, it contributes to important services such as carbon sequestration and water, soil and biodiversity conservation" [1]. This definition emphasizes the importance of achieving the aforementioned objectives through an approach to forest planning that is able to involve different stakeholders [2,3].

The current SFM guidelines are based on planning programmes which seek to identify not only economic, but also social and environmental consequences. These programmes are implemented and evaluated through six criteria (six pan-European criteria ${ }^{1}$ ) and indicators aimed at the maintenance, conservation and adequate improvement of: (i) forest resources and their contribution to global carbon cycles; (ii) the health and vitality of the forest ecosystem; (iii) forest production functions; (iv) biological diversity in forest ecosystems; (v) protective functions in forest management (in particular, soil and water); and (vi) other socio-economic functions and conditions.

At the same time, it is important to highlight the fact that the forest sector is not always able to obtain satisfactory economic returns for the woodlands owned. For this reason, economic sustainability, mainly related to timber production, cannot always compensate for the high management costs.

As argued by Refs. [4-7], this leads to negative profits which, if repeated over time, could become forms of abandonment, with risks related to degradation processes and dangerous consequences mainly related to the loss of ecosystem services.

\footnotetext{
* Corresponding author.

E-mail address: francesco.riccioli@unipi.it (F. Riccioli).

${ }^{1}$ Third Ministerial Conference on the Protection of Forests in Europe, 2-4 June 1998, Lisbon, Portugal.
} 
In order to evaluate the sustainability linked to the various forest management options, ${ }^{2}$ the present paper focuses on coppice, that is, a traditional forest management system exploiting the ability of many broadleaved tree species to regenerate new shoots after cutting (coppicing) from the stool. Coppice is characterized by short rotations, which varying according to tree species and site conditions, ranging from 15 to 20 years up to 50-60 years. This customary management system has left a footprint on the broadleaved forest landscape across Europe since the establishment of the earliest human settlements. Coppice is an anthropogenic system created and optimized for smallsized wood production over several million hectares. The main products, firewood and charcoal, have experienced global use because they have met people's common daily needs such as cooking food and domestic heating, whilst industrial development has produced a further huge demand for energy in recent centuries.

Coppice forests cover about 23 million ha in the Mediterranean area and represent a significant part (over 10\%) of European forest areas [8]. In Italy, coppice forests cover more than 3.6 million ha [9], representing $34 \%$ of total forested area (about 10.6 million ha). Cultivation techniques have been well documented since the Middle Ages [10-12]. Coppice "has had the period of greatest expansion following the increase in energy demand with the first industrial development" [13]. After the middle of the last century, as a consequence of social and economic changes, the use of coppice gradually decreased. The adaptation of this management option to the structural changes of the population has led to a series of "evolutions" concerning its management [14-17].

Since the 1950s, the competitiveness and 'modernity' of fossil fuels, as well as their prompt diffusion, has heavily decreased the use of coppice firewood and charcoal. Former coppice areas have therefore developed into a more composite panorama with stands still managed under the coppice system (traditional coppice), coppice stands left to the process of natural evolution (no silvicultural intervention applied) and coppice stands being converted into high forest [13].

The background is nowadays changing once again following the convergence of two global drivers: firstly, the general awareness that fossil fuels are not remotely a clean energy source, that they will not be easily available in the years to come, and that alternative, renewable energy sources will have to be identified [18]; secondly, global warming has produced gaseous pollutant emissions, and their negative effects can be modelled according to more and more worrying and accurate scenarios by assessing the time limit still at our disposal in order to take corrective measures.

Considering that coppice plays an important role in the national forest economy, one of the objectives of this work is to evaluate its economic, social and environmental sustainability.

Based on SFM criteria and indicators [19], the sustainability of coppices is analysed through two traditional indicators (contribution of the forest sector to GDP and the net revenue of the forest owned) and four innovative indicators (forest sector workforce, trade in wood, energy from wood resources, and accessibility to forest for recreation).

The study area is represented by five forest districts located in the Tuscany Region in Central Italy (Fig. 1), in which the SFM indicators have been calculated in order to evaluate the three above-mentioned coppice management options (traditional coppice, conversion to high forest and natural evolution).

The suitability and effectiveness of the indicators used to evaluate the management of coppice will be interpreted both through a comparison between them, and through any differences between the treatments adopted. In the first phase, each indicator has been analysed in relation to the different management options. Subsequently, the correlations between indicators (both traditional and new) have been considered by examining which of these was mostly influenced by the

\footnotetext{
${ }^{2}$ Option and treatment are used as synonyms in this article
}

examined sites. In particular, these correlations have been analysed using the principal component analysis (PCA) method [20], involving the identification of homogeneous clusters of the sites observed, based on treatment and geographical gradient.

This allowed us to evaluate the eligibility of national/pan-national policy directives and objectives at the local level. Since each of the above analysed indicators promotes different sustainability aspects, their coexistence at a local level, with variable patterns according to the specific context, is heavily addressed. The results highlight the valuable issue of developing updated statistics on coppice forests and on management options, which are at present few in number or even lacking. They constitute, by the way, a fundamental requirement to promote, via suitable SFM Indicators, the sustainable and multifunctional use of the concerned management system, which represents over $10 \%$ of European forest areas, contributing to the aims of the European Forest Strategy.

\section{Materials and methods}

\subsection{Study area}

The Tuscany Region is mainly hilly (66\%), with approximately $9 \%$ of the territory being flatland, while the main mountain ranges (Apuan Alps and Apennine Mountains) cover 25\% of the region. The region is covered by 1.151 million ha of forests, representing $50 \%$ of the total area (2.3 million ha). Deciduous forests represent $38 \%$ of the total (approximately 414,000 ha) and are mostly composed of Turkey oak (Quercus cerris L.), pubescent oak (Q. pubescens Willd.) and Holm oak (Q. ilex L.). The most widespread forest management option is coppice, adopted with respect to 725,000 ha ( $63 \%$ of the total forest area), while the high forests cover 207,000 ha ( $18 \%$ of the total for broadleaved trees) [21].

The case study is represented by five forest districts (highlighted in Fig. 1b), belonging to three provinces, chosen as part of the European project FutureForCoppiceS LIFE14 ENV/IT/000514: the districts of Alpe di Catenaia and Alto Tevere, in the province of Arezzo; the Caselli forests in the province of Pisa; the districts of Colline Metallifere and Alberese, in the province of Grosseto. Each district is composed of areas characterized by different forest species and historical/typical coppice management options: traditional coppice, conversion to high forest, and the natural evolution of coppice.

In total, 34 forest areas were examined, including mountain beech forests (F. sylvatica L.), thermophilous deciduous forests (Turkey oak), and evergreen deciduous forests (Holm oak).

The district of Alpe di Catenaia has an area of approximately 2,341 ha. The common forest species are represented by beech, Turkey oak and mixed broadleaved mesophyll species, with a marked (progressive) reduction in coppice and a simultaneous increase in transitional forests.

The Alta Valle del Tevere District is located in the pre-Apennine submountainous vegetation belt with a prevalence of deciduous oaks (Turkey oaks) and black hornbeam (Ostrya carpinifolia Scop.), which characterizes the upper part of the Tevere Basin and covers an area of 4,321 ha.

The Colline Metallifere District covers a total area of approximately 15,237 ha with prevalence of deciduous oaks (Turkey oak), hornbeam and Holm oak.

The Alberese District belongs to Maremma Park, extending over a wide strip of the Grosseto Coast and covering approximately $21 \mathrm{~km}$ (total area: 9,009 ha), with a prevalence of evergreen broadleaves (Holm oak).

Finally, the Caselli District covers an area of approximately 1,375 has where forests are mainly represented by deciduous oaks (Turkey oaks). 
(A)

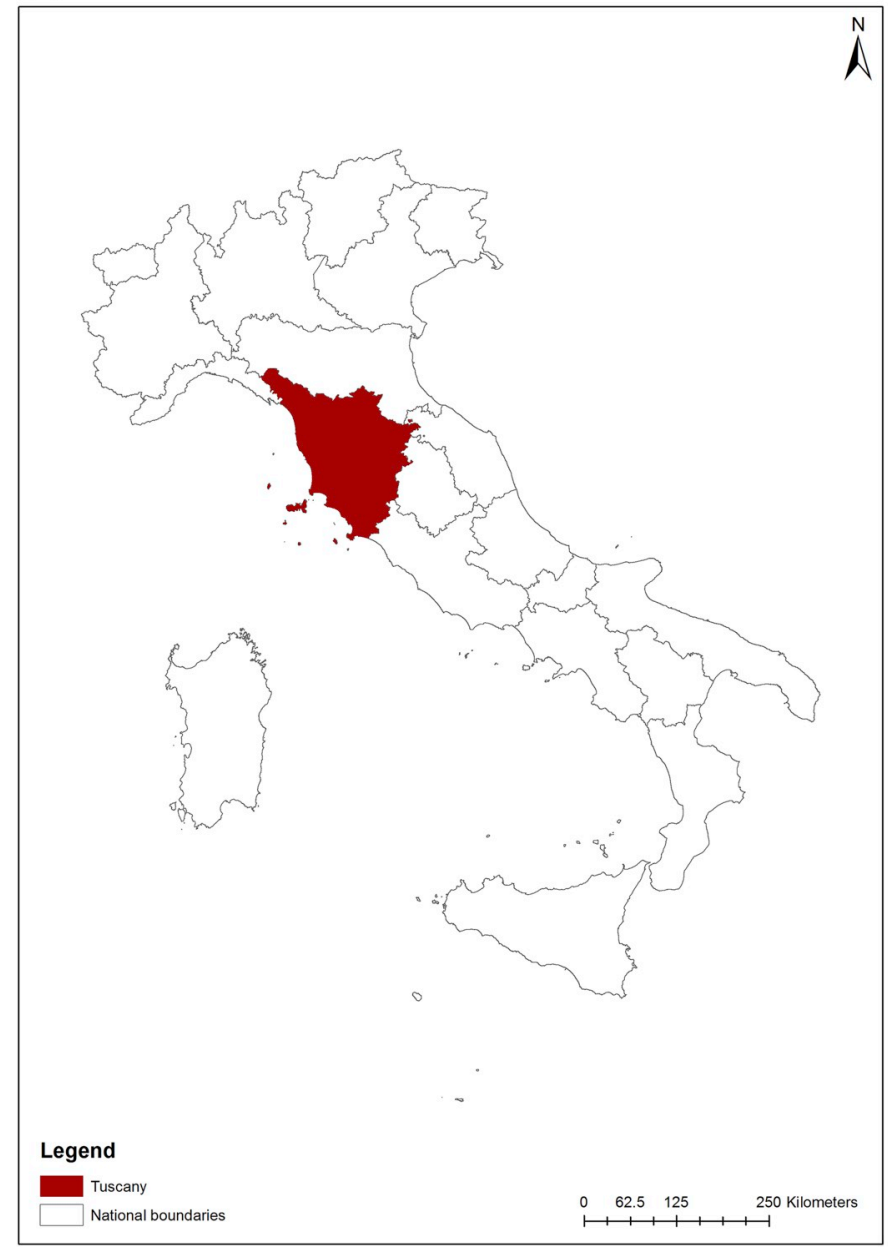

(B)

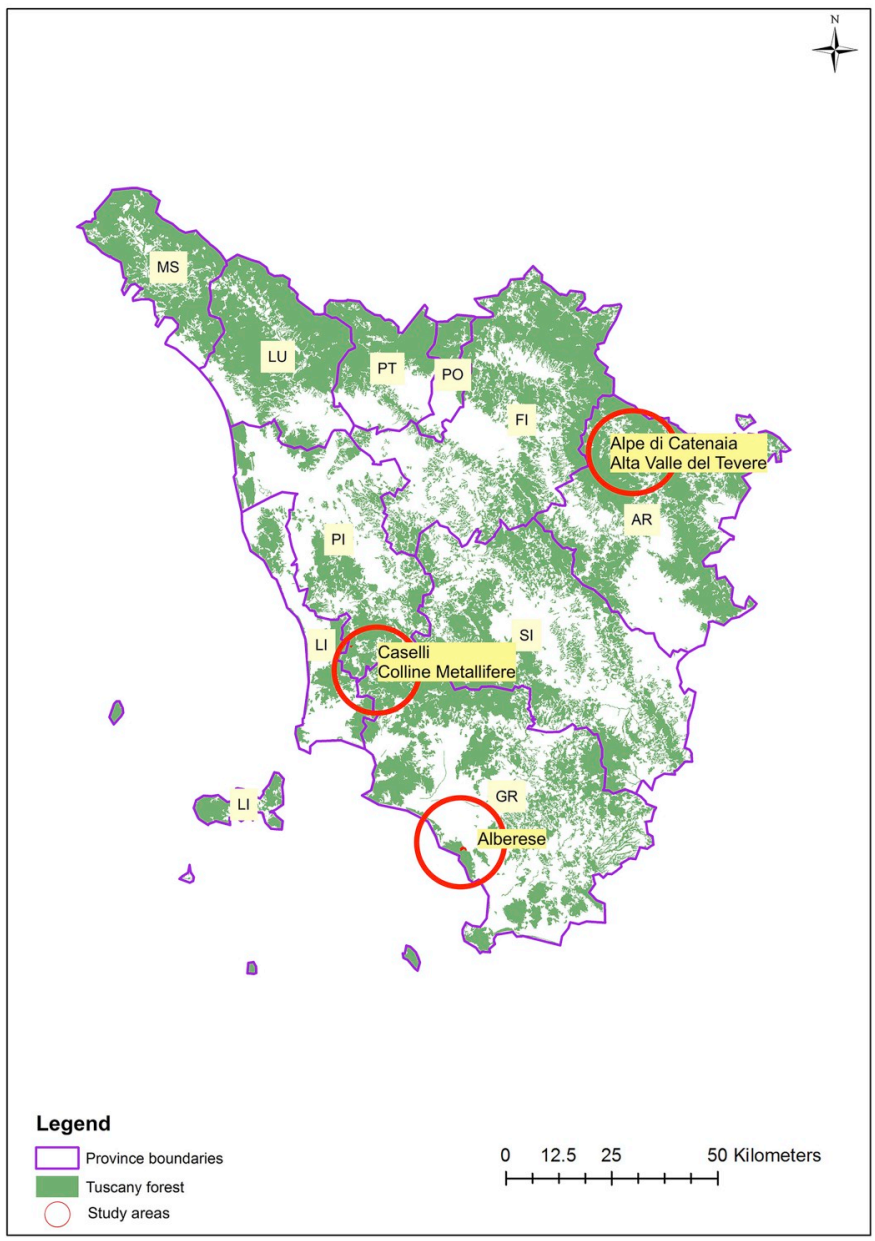

Fig. 1. Study areas.

\subsection{Data collection}

The SFM indicators analysed are shown in Table 1.

The data measured by each indicator refer to surfaces with different levels of detail. The different scales of detail, in some cases, did not allow for a comparison of the options: this is the case with the forest workforce indicator, calculated with a suburban detail, and the tradein-wood indicator calculated by district; in all other cases, a comparison was possible.

The analysis is mainly based on the CRA-SEL (Research Centre for Forestry) database. This contains a historical set of data from over 50 long-term experimental fields located in Tuscany from 1968 to present; for each field, the database provides some dendrometric data such as height, diameter, basal area, number of shots, standing volume and standing biomass.

For the analysis of Indicator 6 (accessibility for recreation), a questionnaire (see the Appendix for more details) was prepared and administered to a sample of users of forest located in our case study area (number of interviews: 248).

\subsection{Data analysis and processing}

\subsubsection{Contribution of the forest sector to GDP}

This indicator represents the percentage of the contribution of the forest sector in terms of added value compared to the added value of agriculture of Tuscany. It is therefore intended to evaluate how much the quantity of timber produced at the district level affects the added value of agriculture (this also includes the forestry and fishing sectors) which in Tuscany is $2.8 \%$ [22]. For its determination, the value of wood production expressed in market prices was considered, with the net value of intermediate consumption (purchase of timber, salaries of personnel, diesel for machines, general expenditures, etc.) calculated on the basis of market prices (Equation (1)).

Table 1

Environmental socio-economic SFM indicators.

\begin{tabular}{|c|c|c|c|c|}
\hline ID & SFM Indicator & Type & Scale & Unit of measurements \\
\hline 1 & Contribution of Forest sector to GDP & Traditional & Area $\left(10^{1}-10^{3} \mathrm{~km}^{2}\right)$ & $\%$ \\
\hline 2 & Net Revenue & Traditional & Area $\left(10^{1}-10^{3} \mathrm{~km}^{2}\right)$ & $€ /$ ha per year \\
\hline 3 & Forest Sector Workforce & Innovative & Province $\left(10^{3} \mathrm{~km}^{2}\right)$ & Specialization index \\
\hline 4 & Trade in Wood & Innovative & District $\left(10^{2}-10^{3} \mathrm{~km}^{2}\right)$ & $\mathrm{m}^{3} /$ year \\
\hline 5 & Energy from wood resources & Innovative & Area $\left(10^{1}-10^{3} \mathrm{~km}^{2}\right)$ & $\mathrm{MWh}_{\mathrm{t}} /$ ha per year \\
\hline 6 & Accessibility for recreation & Innovative & Area $\left(10^{1}-10^{3} \mathrm{~km}^{2}\right)$ & $€ /$ year \\
\hline
\end{tabular}


$V A_{f}=\frac{V_{\text {ass }}-C_{\text {int }}}{V A_{\text {tosc }}}$

where:

$\mathrm{VA}_{\mathrm{f}}=$ forestry added value (expressed in $\%$ of the added value of agriculture in Tuscany)

$\mathrm{V}_{\text {ass }}=$ timber production value ( $€ /$ ha year)

$\mathrm{C}_{\text {int }}=$ intermediate consumption $(€ /$ ha year $)$

$\mathrm{VA}_{\text {tosc }}=$ added value of agriculture in Tuscany (expressed in $€ /$ year/ha of agricultural area used)

\subsubsection{Net revenue}

To estimate this indicator (capitalization of periodical land income of property), it is important to detect the amount (in $\mathrm{m}^{3}$ ) of related forest utilization [9] at the district level. Thanks to these data, according to the formula proposed by Ref. [23], the value of stumpage has been calculated (Equation (2)):

$P t=V_{\text {ass }}-K_{\text {trasf }}$

where:

$$
\begin{aligned}
& \mathrm{Pt}=\text { stumpage value per year }(€ / \mathrm{ha}) \\
& \mathrm{V}_{\text {ass }}=\text { timber production value }(€ / \mathrm{ha}) \\
& \mathrm{Kt}_{\text {rasf }}=\text { processing costs }(€ / \mathrm{ha})
\end{aligned}
$$

For the calculation of the net revenues (for coppices and for conversion to high forest areas), different formulas were considered by using different discount rates. Indeed, as argued by Refs. [24-26], the discount rate is one of the most efficient parameters used in economic estimations to calculate and predict future scenarios.

Equation (3) is related to coppice treatment.

$N R_{c}=\left(P t-s \frac{q^{t}-1}{r}\right) \cdot \frac{1}{q^{t}-1}$

where:

$\mathrm{NR}_{\mathrm{c}}=$ net revenue of the coppice $(€ / \mathrm{ha})$

$\mathrm{s}=$ expenditures for management, administration, etc. $(€ /$ ha/year $)$

$\mathrm{q}=1+\mathrm{r}$ with $\mathrm{r}=$ discount/capitalization rate

$\mathrm{t}=$ rotation of the coppice (number of years)

By considering the net revenue of conversion to high forest areas, two periodic incomes were considered: one relating to the transitory stand (Equation (4)) and one relative to the future permanent one (Equation (5)).

$N R_{\text {trans }}=\left(P t+\left(P_{m} \cdot q^{n-m}\right)-s \frac{q^{n}-1}{r}\right) \cdot \frac{1}{q^{n}}$

where:

$\mathrm{NR}_{\text {trans }}=$ net revenue of the transitory stand $(€ /$ ha)

$\mathrm{P}_{\mathrm{m}}=$ intermediate value obtained from thinning $(€ / \mathrm{ha})$

$\mathrm{n}=$ rotation of the transitory stand (number of years)

$\mathrm{m}=$ timing (year) of thinning

$N R_{\text {def }}=\left[\left(P t+\left(P_{m} \cdot q^{t-m}\right)-s \frac{q^{t}-1}{r}\right) \cdot \frac{1}{q^{t}-1}\right] \cdot \frac{1}{q^{t-j}}$

where:

$\mathrm{NR}_{\text {def }}=$ net revenue of permanent high forest $(€ /$ ha)

$\mathrm{m}=$ year of beginning of natural renewal, corresponds to the year in

which the cut seeding takes place

$\mathrm{t}=$ year of the cut seeding

$\mathrm{j}=$ year of the first cutting for conversion to high forest.
In order to obtain an annual value, the net revenue (both of the coppice and of the conversion to high forest) was subsequently annualized using Equation (6).

$N R_{a}=N R \cdot \frac{r \cdot t}{q^{t}-1}$

where:

$\mathrm{NR}_{\mathrm{a}}=$ annual net revenue $(€ /$ ha/year $)$

$\mathrm{NR}=$ net revenue of the coppice $\left(\mathrm{NR}_{\mathrm{c}}\right)$ and conversion to high forest (NRtrans and $\left.\mathrm{NR}_{\mathrm{def}}\right)$ areas $(€ / \mathrm{ha})$

$\mathrm{t}=$ rotation of the coppice and of conversion to high forest areas (number of years)

\subsubsection{Forest-sector workforce}

For the calculation of this indicator, a specialization index was created based on the number of employees at the provincial level provided by the CCIAA ${ }^{3}$ database and ISTAT [27] (data related to the district level are not available).

This index (Equation (7)) linked, at both provincial and regional levels, the number of forestry-sector operators with the number of the agriculture-sector operators (agriculture, forestry and fishing) defined according to the ATECO classification $[23,28]$.

$I S=\frac{\sum_{i=1}^{n} A s_{i} / \sum_{i=1}^{n} A a_{i}}{\sum_{j=1}^{n} A s_{j} / \sum_{j=1}^{n} A a_{j}}$

where:

IS $=$ specialization index

$\mathrm{As}_{\mathrm{i}}=$ number of forestry-sector operators of the $i$-th province

$\mathrm{Aa}_{\mathrm{i}}=$ number of agriculture-, forestry- and fishing-sector operators of

the $i$-th province

$\mathrm{As}_{\mathrm{i}}=$ number of forestry-sector operators of the $i$-th region

$\mathrm{Aa}_{\mathrm{i}}=$ number of agriculture-, forestry- and fishing-sector operators of

the $i$-th region

This index is a measure of the dissimilarity between the provincial number and the regional number of forestry-sector operators, and describes the specialization concerning the forest workforce of a province compared to the regional average situation (number of forestry-sector operators in the total number of agriculture-, forestry- and fishing-sector operators in Tuscany). The range of variation is always between -1 and +1 : the minimum value $(-1)$ is observed in the provinces where no forest operators are present; values close to zero (0) are noted in the provinces where the number of forestry operators is similar to that recorded at the regional level (absence of specialization); the maximum value $(+1)$ can be observed if all the operators of a province are concentrated in the silvicultural sector and if, at the same time, all the operators of the silvicultural sector are concentrated in that single province (maximum specialization).

\subsubsection{Trade in wood}

This indicator has been calculated considering the potential yield (monitoring period: 2012-2015) provided by the forest management plans for the regional property supplied by the Tuscany Region [29]. The quantity obtained, referred to as regional property, comprises average annual data which correspond to an amount (in $\mathrm{m}^{3}$ ) of timber produced and introduced in the local and extra-regional market. A comparison with the ISTAT data was not possible because the data available from the ISTAT database are available at the regional level or, only for a few years, at the provincial level [30]; therefore, there is no correspondence between official statistics and the data calculated by

\footnotetext{
${ }^{3}$ Chamber of Commerce, Industry, Crafts and Agriculture.
} 
this indicator.

\subsubsection{Energy from wood resources}

This indicator seeks to highlight the potentiality for the production of energy from wood resources, mainly based on biomass products. The energy use of wood biomass has seen significant growth in recent years [31] and the EU policy that focuses on this sector has reinforced this position. Indeed, the EU aims to "reduce GHG emissions by at least $40 \%$ below 1990 levels by 2030; moreover within the framework of the Paris Agreement, the European Commission also submitted, in November 2018, a strategy for a climate neutral economy by 2050 , providing a cost-efficient trajectory towards the attainment of the target of net-zero emissions" [32].

Biomass can be obtained both as a main product and as a residue of timber cuttings. Among the products that characterize the biomass market, woodchips are certainly the most economical when considering the various existing commercial types. For the period 2010-2015, at the statistical level, reference was made to the forest utilization of Tuscany according to the ISTAT forest statistics [30], integrated at municipal level by data from the IBioNet Observatory [33].

The determination of the energy potential of wood biomass takes into account some fundamental physical parameters, such as calorific value expressed in megawatt thermal hours $\left(\mathrm{MWh}_{\mathrm{t}}\right)$ and the degree of humidity present in the wood (Table 2 ).

The energy from wood resources was calculated starting with the quantity of woodchips obtainable from residuals of forest utilization [4] in the experimental areas considered. Subsequently, this datum has been multiplied by its lower caloriferous power (PCI), which varies according to the species and the water content [34]. Using an average efficiency of a heat-generating plant, an estimate of the energy that the forest resources can produce was obtained $[35,36]$.

$E_{i}=T_{i} \cdot P C I \cdot R$

where:

$E_{i}=$ energy from woody resources of the $i$-th study area $\left(M^{\prime} h_{t} /\right.$ year)

$\mathrm{T}_{\mathrm{i}}=$ chips obtained from residuals of forest utilizations in the $i$-th municipality ( $\mathrm{t} /$ year)

$\mathrm{PCI}=$ lower heating power $\left(\mathrm{MWh}_{\mathrm{t}} / \mathrm{t}\right)$

$\mathrm{R}=$ average efficiency of a heat generation plant (\%)

\subsubsection{Accessibility for recreation}

The methodology used to determine this indicator is the contingent valuation method (CVM) which aims to analyse consumers' choice regarding environmental goods, through the use of questionnaires and interviews [36-40]. Considering a sample of respondents, this method allows us to analyse the willingness to pay (WTP) for the three forest management options.

The hypothetical scenario included a supplement to income tax at a regional level, that is, a payment method by which we expected respondents to pay for maintaining the recreational value of the forest area.

A total of 248 respondents were selected taking into account the results obtained during pre-sampling, which was carried out on 30 randomly chosen individuals including forest users, tourists and

Table 2

Wood moisture content and heating power for forest species.

\begin{tabular}{lll}
\hline Wood species & Humidity & PCI \\
\cline { 2 - 3 } & $\%$ & $\mathrm{MWh}_{\mathrm{t}} / \mathrm{t}$ \\
\hline Beech & $12-15$ & 4 \\
Turkey oak & $12-15$ & 4.2 \\
Holm oak & $12-15$ & 4.2 \\
\hline
\end{tabular}

university students.

Cluster random sampling was adopted: participants were randomly selected by considering geographically well-defined areas. The territory was divided into geographical sub-areas belonging to the municipality they belong to, or in some cases, the municipalities adjacent to the study area. The interviews were carried out between July and September 2016.

The analysis of respondents indicates that the sample of 248 respondents was composed of $46 \%$ males and $54 \%$ females. The sample shows a high level of education attainment, with $66 \%$ of respondents having a high school degree and $18 \%$ with a master's degree. Those who attended only secondary school made up $15 \%$ of the sample, while $2 \%$ attended only primary school. Concerning age, $40 \%$ of the sample was made up of young people (18-35 years old), while $27 \%$ were aged between 35 and 50 years. The remaining percentages (24\% and 9\%) were people aged between 50 and 65 years and people older than 65 years, respectively. The occupation variable revealed the highest percentage with employed people at $30 \%$, followed by students at $29 \%$. Retired people and freelancers represented $12 \%$ of the sample, while housekeepers and unemployed people corresponded to $9 \%$ and $8 \%$, respectively.

The elicitation method was based on the revised multiple price list method [41,42] and adopted a payment card to allow for the availability to pay. The payment card method was adopted due to its easy application and because it imposed only a low cognitive burden on respondents $[43,44]$.

Each respondent expressed his maximum WTP for each forest option by choosing between 12 price ranges from 0 (no WTP) to $22 € /$ year (each interval differed by $2 €$ ).

We established the WTP bid range by analysing the annual users in the study areas: based on previous work [4,5], for each user, an average annual amount was calculated for optimal forest maintenance (approximately $11 € /$ year). The upper limit was set twice.

The general assumption underlying this model, as argued by Refs. $[46,47]$, is that the real WTP of each interviewee is found randomly between the chosen value and the subsequent upper value. The estimation of the real WTP was therefore based on the random effects interval data regression model (Equation (9)) implemented in a previous study [48].

$W T P i j=\alpha+\gamma 1 E+\gamma 2 H+\xi i+\xi i j$

where:

$W T P_{i j}=$ the dependent variable (WTP) of $i$-th respondent related to $j$-th forest management option

$\alpha=$ the intercept

$\gamma_{1}$ and $\gamma_{2}=$ the estimated coefficients, i.e., the WTP difference between the three forest management approaches

$E$ and $H=$ the effect-coded dummy variables representing the natural evolution and high forest management systems, respectively

To account for the random effects, we spilt the residual $\varepsilon_{i j}$ into two components. The component $\zeta_{i}$ is specific for each subject and constant for each $j$-th forest management system, while the idiosyncratic component $\xi_{i j}$ is specific to each $j$-th forest management system for each $i$-th respondent.

\subsubsection{Statistical processing}

The data are analysed by using the following statistical processes:

- Correlation matrices among SFM indicators with the calculation of the regression coefficient and related statistical significance values (Pearson's correlations; p-value);

- non parametric Kruskal Wallis rank sum test has been performed to test the differences in the indicators among the three treatments. Mann-Whitney test has been used for post-hoc pairwise 
comparisons;

- Multivariate analysis - PCA [49] was used as an exploratory multivariate unsupervised analysis approach (indirect analysis of gradients) to study the trend of the six SFM indicators in relation to the three management options used in the 34 forest areas.

PCA is widely adopted in environmental analysis [49-53]; it is a statistical method aimed at analysing data by reducing the number of variables within the data to a limited number of linear combinations (linearly uncorrelated variables). As argued by Ref. [20], "each linear combination will correspond to a principal component" while cluster analysis "refers to a very broad set of techniques for finding subgroups, or clustering clusters, in a data set; when we cluster the observations of a data set, we seek to partition them into distinct groups so that the observations within each group are quite similar to each other, while observations in different groups are quite different from each other" [55].

The analyses were performed using $\mathrm{R}$ open-source statistical software (R Core Team 2018).

\section{Results}

The results of the analyses led to the quantification of six indicators for each of the 34 areas present in the five forest districts considered (Table 3).

It is important to underline the data on the contribution of the forestry sector to GDP, net revenue and energy from wood products from natural evolution areas, as these were expressed with a negative value: this is essentially due to the fact that, by not cutting the forest, the data express a lack of income, expressing the cost of the refusal to cut the forest floor.

The greatest contribution of forests to added value is given by the conversion to high forest areas in Colline Metallifere and Alto Tevere, at about $0.031 \%$ (Table 3 ). The highest net incomes were recorded in the traditional coppice areas of Colline Metallifere (58.55€/ha per year). Regarding the forest workforce, it is possible to see how the provinces with a specialization index higher than the regional average were Arezzo and Pisa (1.71 and 1.02, respectively), while Grosseto shows a specialization lower than the regional average (0.52). The maximum values of potentially marketable assortments were recorded in the forest district of Alto Tevere $\left(20,300 \mathrm{~m}^{3} /\right.$ year) while the lowest values were recorded in the Caselli District $\left(2,750 \mathrm{~m}^{3}\right.$ /year). The highest values of the indicator concerning energy from wood resources were found in the conversion areas of the Alberese District with $2.09 \mathrm{MWh}_{\mathrm{t}} /$ ha per year while the lowest were found in the natural evolution areas (same district) with a non-production of $2.09 \mathrm{MWh}_{\mathrm{t}} /$ ha per year. Finally, in terms of accessibility to recreation, the highest value of WTP is related to conversion to high forest areas in the Alberese District ( $8.88 €$ /year), while the lower value belongs to the natural evolution area in the district of Alto Tevere (6.72€/year).

Except for the forest workforce and wood trade, conversion to high forest showed the highest values followed by traditional coppice and natural evolution stands for most of the indicators (Fig. 2), with significant differences among treatments $(\mathrm{p}<0.001)$ and marked differences between natural evolution and the other two treatments (Table 4).

Some exceptions were recorded for the net revenue in the Colline Metallifere district where the highest values were found in relation to the traditional coppice followed by conversion to high forest. Another exception is the indicator relating to recreational values in the Alpe di

Table 3

Calculation of indicators by district, area and form of option.

\begin{tabular}{|c|c|c|c|c|c|c|c|c|c|}
\hline \multirow[t]{2}{*}{ Area } & \multirow[t]{2}{*}{ District } & \multirow[t]{2}{*}{ Managem. option } & \multirow[t]{2}{*}{ Province } & GDP & Net revenue & Workforce & Trade & Energy & \multirow{2}{*}{$\begin{array}{l}\text { Recreation } \\
€ / \text { year }\end{array}$} \\
\hline & & & & $\%$ & $€ /$ ha per year & Spec. index & CM/year & $\mathrm{MWh}_{\mathrm{t}} /$ ha per year & \\
\hline 1 & Catenaia & coppice & $\mathrm{Ar}$ & 0.0141 & 24.03 & 1.714 & 15,797 & 1.066 & 7.55 \\
\hline 2 & Catenaia & coppice & $\mathrm{Ar}$ & 0.0177 & 35.31 & 1.714 & 15,797 & 1.335 & 7.55 \\
\hline 3 & Catenaia & coppice & $\mathrm{Ar}$ & 0.0146 & 34.00 & 1.714 & 15,797 & 1.106 & 7.55 \\
\hline 4 & Catenaia & coppice & $\mathrm{Ar}$ & 0.0137 & 29.51 & 1.714 & 15,797 & 1.039 & 7.55 \\
\hline 5 & Catenaia & conversion & $\mathrm{Ar}$ & 0.0079 & 48.92 & 1.714 & 15,797 & 1.470 & 8.80 \\
\hline 6 & Catenaia & conversion & $\mathrm{Ar}$ & 0.0256 & 43.50 & 1.714 & 15,797 & 1.640 & 8.80 \\
\hline 7 & Catenaia & conversion & $\mathrm{Ar}$ & 0.0264 & 48.07 & 1.714 & 15,797 & 1.690 & 8.80 \\
\hline 8 & Catenaia & conversion & $\mathrm{Ar}$ & 0.0244 & 46.90 & 1.714 & 15,797 & 1.760 & 8.80 \\
\hline 9 & Catenaia & conversion & $\mathrm{Ar}$ & 0.0285 & 47.20 & 1.714 & 15,797 & 1.830 & 8.80 \\
\hline 10 & Catenaia & natural ev. & $\mathrm{Ar}$ & -0.0190 & -39.84 & 1.714 & 15,797 & -1.493 & 8.64 \\
\hline 11 & Catenaia & conversion & $\mathrm{Ar}$ & 0.0167 & 41.00 & 1.714 & 15,797 & 1.990 & 7.44 \\
\hline 12 & Alto Tevere & conversion & $\mathrm{Ar}$ & 0.0303 & 37.75 & 1.714 & 20,362 & 1.460 & 7.52 \\
\hline 13 & Alto Tevere & conversion & $\mathrm{Ar}$ & 0.0192 & 43.06 & 1.714 & 20,362 & 1.100 & 7.52 \\
\hline 14 & Alto Tevere & conversion & $\mathrm{Ar}$ & 0.0215 & 47.29 & 1.714 & 20,362 & 1.230 & 7.52 \\
\hline 15 & Alto Tevere & natural ev. & $\mathrm{Ar}$ & -0.0237 & -42.70 & 1.714 & 20,362 & -1.263 & 6.72 \\
\hline 16 & Alberese & conversion & $\mathrm{Gr}$ & 0.0240 & 34.84 & 0.519 & 4,500 & 2.088 & 8.88 \\
\hline 17 & Alberese & natural ev. & $\mathrm{Gr}$ & -0.0240 & -34.84 & 0.519 & 4,500 & -2.088 & 7.04 \\
\hline 18 & Alberese & natural ev. & $\mathrm{Gr}$ & -0.0240 & -34.84 & 0.519 & 4,500 & -2.088 & 7.04 \\
\hline 19 & C. Metall. & natural ev. & $\mathrm{Gr}$ & -0.0245 & -47.53 & 0.519 & 4,975 & -1.027 & 7.52 \\
\hline 20 & C. Metall. & coppice & $\mathrm{Gr}$ & 0.0225 & 41.10 & 0.519 & 4,975 & 0.940 & 7.60 \\
\hline 21 & C. Metall. & conversion & $\mathrm{Gr}$ & 0.0305 & 42.94 & 0.519 & 4,975 & 1.280 & 8.32 \\
\hline 22 & C. Metall. & coppice & $\mathrm{Gr}$ & 0.0205 & 58.55 & 0.519 & 4,975 & 0.860 & 7.60 \\
\hline 23 & Caselli & conversion & $\mathrm{Pi}$ & 0.0292 & 42.73 & 1.016 & 2,750 & 1.300 & 8.40 \\
\hline 24 & Caselli & conversion & $\mathrm{Pi}$ & 0.0241 & 31.53 & 1.016 & 2,750 & 1.070 & 8.40 \\
\hline 25 & Caselli & conversion & $\mathrm{Pi}$ & 0.0292 & 42.73 & 1.016 & 2,750 & 1.300 & 8.40 \\
\hline 26 & Caselli & conversion & $\mathrm{Pi}$ & 0.0241 & 31.53 & 1.016 & 2,750 & 1.070 & 8.40 \\
\hline 27 & Caselli & conversion & $\mathrm{Pi}$ & 0.0292 & 42.73 & 1.016 & 2,750 & 1.300 & 8.40 \\
\hline 28 & Caselli & conversion & $\mathrm{Pi}$ & 0.0241 & 31.53 & 1.016 & 2,750 & 1.070 & 8.40 \\
\hline 29 & Caselli & conversion & $\mathrm{Pi}$ & 0.0292 & 42.73 & 1.016 & 2,750 & 1.300 & 8.40 \\
\hline 30 & Caselli & conversion & $\mathrm{Pi}$ & 0.0241 & 31.53 & 1.016 & 2,750 & 1.070 & 8.40 \\
\hline 31 & Caselli & natural ev. & $\mathrm{Pi}$ & -0.0267 & -37.13 & 1.016 & 2,750 & -1.185 & 7.24 \\
\hline 32 & Caselli & natural ev. & $\mathrm{Pi}$ & -0.0267 & -37.13 & 1.016 & 2,750 & -1.185 & 7.24 \\
\hline 33 & Caselli & natural ev. & $\mathrm{Pi}$ & -0.0267 & -37.13 & 1.016 & 2,750 & -1.185 & 7.24 \\
\hline 34 & Caselli & natural ev. & $\mathrm{Pi}$ & -0.0267 & -37.13 & 1.016 & 2,750 & -1.185 & 7.24 \\
\hline
\end{tabular}



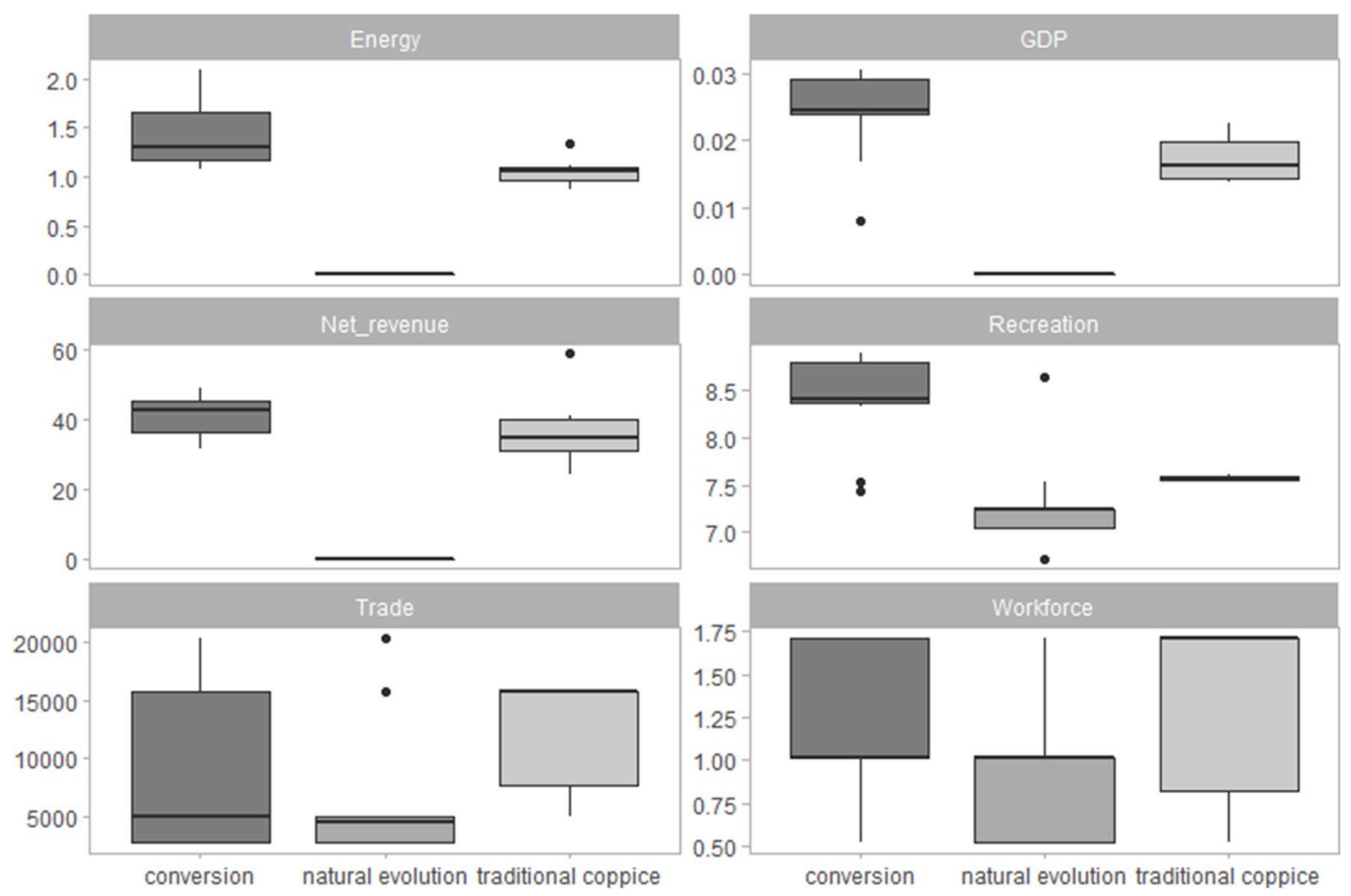

Fig. 2. Descriptive statistics for the six SFM indicators considering the three management options. Box plot: median, 1.5 interquartile range, outliers.

Table 4

Comparison of the values of each indicator among treatments (Kruskal Wallis test) and pairwise comparisons (post-hoc Mann-Whitney test). ${ }^{*} \mathrm{p}<0.05$; $* * \mathrm{p}<0.01 ; * * * \mathrm{p}<0.001$, ns: not significant, NA: not assessed.

\begin{tabular}{|c|c|c|c|c|}
\hline \multirow[t]{2}{*}{ Indicator } & \multirow{2}{*}{$\begin{array}{l}\text { Kruskal } \\
\text { Wallis test } \\
\text { (p-value) }\end{array}$} & \multicolumn{3}{|c|}{ Post-hoc pair comparison (Mann-Whitney test) } \\
\hline & & $\begin{array}{l}\text { natural } \\
\text { evolution vs } \\
\text { conversion }\end{array}$ & $\begin{array}{l}\text { traditional } \\
\text { coppice vs } \\
\text { conversion }\end{array}$ & $\begin{array}{l}\text { traditional } \\
\text { coppice vs } \\
\text { natural } \\
\text { evolution }\end{array}$ \\
\hline Energy & $* * *$ & $* * *$ & $* *$ & $* * *$ \\
\hline GDP & $* * *$ & $* * *$ & $* *$ & $* * *$ \\
\hline Net_revenue & $* * *$ & $* * *$ & $\mathrm{~ns}$ & $* * *$ \\
\hline Recreation & $* * *$ & $* * *$ & * & * \\
\hline Trade & ns & NA & NA & NA \\
\hline Workforce & ns & NA & NA & NA \\
\hline
\end{tabular}

Catenaia district where the highest medians were registered for conversion to high forest woods followed by natural evolution while the traditional coppice obtained in this case lower values.

When considering the correlation between traditional and innovative indicators (Table 5), the contribution of the forest sector to GDP is positively related with high net revenue and high values of energy obtainable yearly from the woodchips, as well as high recreational values, thus showing the high added value of wood production.

Table 5

Matrix of correlation coefficients between indicators ("significant p-values < $0.05)$.

\begin{tabular}{llllll}
\hline Indicators & GDP & Net Revenue & Workforce & Trade & Energy \\
\hline GDP & 1.0000 & - & - & - & - \\
Net Revenue & $0.8689^{*}$ & 1.0000 & - & - & - \\
Workforce & 0.0883 & 0.2429 & 1.0000 & - & - \\
Trade & 0.0368 & 0.2534 & $0.8621^{*}$ & 1.0000 & - \\
Energy & $0.8394^{*}$ & $0.8834^{*}$ & $0.3474^{*}$ & 0.3160 & 1.0000 \\
Recreation & $0.6432^{*}$ & $0.5851^{*}$ & 0.1130 & -0.0458 & $0.6594^{*}$
\end{tabular}

The net revenue is further correlated with energy and recreation, associating high incomes with high energy values obtainable yearly from wood residues and high recreational values. With regard to the forest workforce, two correlations have been noted, which indicate that a high degree of specialization among the forest workforce is correlated with high annual quantities of marketable timber and with high values of energy annually obtainable from woodchips. Finally, the last correlation related to the energy indicator explains the high values of energy obtainable annually from woodchips with high recreational values.

The traditional and innovative indicators were also analysed using PCA. This multivariate form of analysis has been applied to forest research in previous studies [52,55-58].

The ordering explains a total of $87 \%$ of the total variance (Fig. 3) and shows an interesting trend in the variables in relation to the treatment (Axis 1) and the relevant district (Axis 2). In particular, Axis 1 explains $57 \%$ of the variance (Table 6) and separates the areas regardless of their geographical distribution, thus merging plots belonging to different districts. On this axis, however, it is possible to clearly distinguish the plots on the basis of treatment: the conversions to high forest and the coppices were distributed according to positive values of the axis, while natural evolution areas were distributed according to negative values of the axis. Axis 2, which explains $30 \%$ of the variance (Table 6), separates the areas, based on their geographical distribution in the Casentino area (Alpe di Catenaia and Alto Tevere Districts; Plot IDs 1 to 15, see Fig. 3 and Table 6) and distributed according to positive values, regardless of treatment. For negative values, the areas in the Alberese, Colline Metallifere and Caselli Districts were distributed instead (Plot IDs 16 to 34; Fig. 3 and Table 6).

PC1 from the ordination is closely linked with the energy and net revenue indicators, while PC2 is mainly correlated with the indicators for workforce and wood trade (Fig. 3), both with positive loadings, as opposed to all others characterized by negative loadings. It is also possible to highlight how the indicators for trade in wood and forestry workforce have a prevalent influence on the conversion to high forest areas in Casentino (positive quadrant of Axes 1 and 2). All other indicators (GDP, net revenue, energy and recreation) mainly influence the 


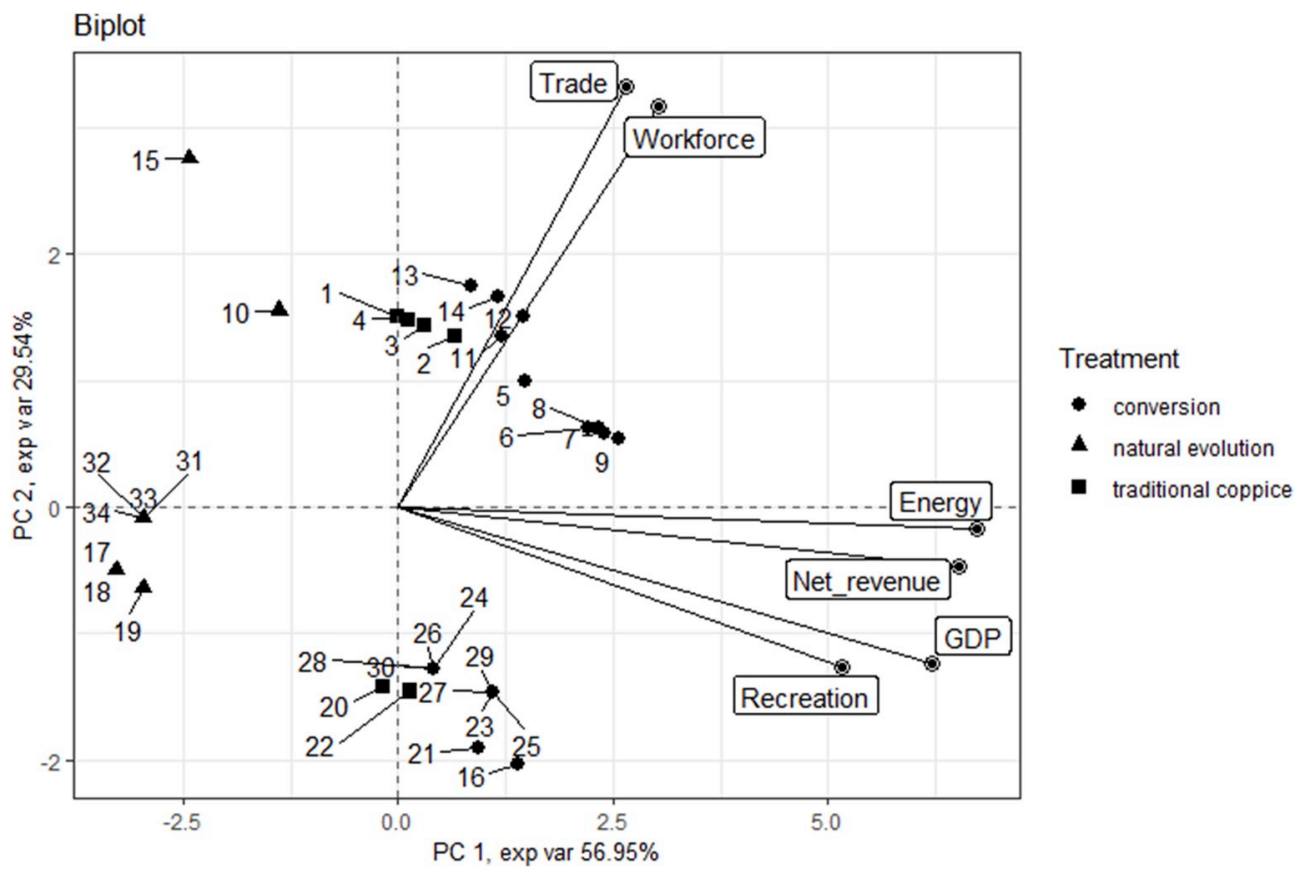

Fig. 3. Scores plot from the PCA. The 34 areas examined are listed and categorized with respect to the three treatments.

Table 6

Loadings plot from the PCA (variance in brackets).

\begin{tabular}{lll}
\hline Indicators & PC $1(56.95 \%)$ & PC 2 (29.54\%) \\
\hline GDP & 0.4772 & -0.2507 \\
Net Revenue & 0.5015 & -0.0935 \\
Workforce & 0.2333 & 0.6398 \\
Trade & 0.2032 & 0.6726 \\
Energy & 0.5174 & -0.0348 \\
Recreation & 0.3967 & -0.2556 \\
\hline
\end{tabular}

conversion to high forest areas in Caselli.

\section{Discussion}

Despite some indicators not being comparable with other studies (mainly due to different scales used), data related to net revenue and recreation provide similar outcomes.

Considering the Forest Europe Report [19], net revenues are as follows: South-eastern Europe $36 € /$ ha, South-western Europe $88 € /$ ha, Central Eastern Europe $97 € /$ ha, Central Western Europe $144 € /$ ha, Northern Europe $109 € /$ ha, average value for Europe (28 countries) $114 € /$ ha. Only the results related to South-eastern Europe are comparable with our net revenues, probably because, in the other areas, there is a predominance of high forest compared to coppice.

Our recreational values can be compared with the results of other authors [59]: register about 20€/year for Mediterranean forests [60], obtain 19€/year for forests located in Colline Metallifere [61], report $12.54 €$ /year for forested areas in Sicily, while [62] calculate $4 € /$ year for forest in Central Italy.

From the analysis of the obtained results, it is possible to outline some points of reflection to better understand how the indicators can improve forest management in the examined areas.

Some considerations can be drawn from the comparison between the indicators taking the management options into account: conversion to high forest is a treatment that has a high degree of influence on forest management, characterized by long turnover and income delays over time. The high median values found in four out of the six indicators can be explained by the fact that the possibility to obtain and process larger wood assortments, compared to coppice-based material, appears to be a strength, in terms of added value, net revenue and energy. At the same time, however, it is noted that, for traditional coppice, values for the indicators related to the trade in wood and the workforce are high: this can be explained by the fact that this management option is closely linked to specialized forest workforce activity. Indeed, the cutting of coppice requires high specialization because the stump must release new shots and the "quality" of cutting operations influences the quantity and quality of regrowth. Moreover, high specialization is related to selective coppices located in Catenaia [62,63].

Concerning trade in wood, the values observed are influenced by the coppice characteristics that guarantee wood production takes less time compared to high forest management. Indeed, the assortment related to coppice (principally firewood) is required in the regional and extraregional market.

The indicator for recreation reveals that the significant high values of conversion to high forest are relative to the perception that people have of the forest. In this case, conversion is the option that most resembles a high forest, therefore it is pleasing to visitors. This treatment is preferred with respect to coppice that is more influenced by the cuts and to natural evolution, which can represent a form of abandonment less suitable for recreational activity. Despite this, natural evolution generates WTP, probably because the natural concept can be associated with wilderness or naturalness ones (widely studied in the literature [64-69]).

Natural evolution is also related to negative values, due to the nonuse of the resource, which, therefore, from an economic point of view, is equivalent to a loss of income. However, if we consider this aspect from a socio-environmental point of view, the perception may be different, as demonstrated by the indicator for recreation, where natural evolution, despite being the least preferred treatment among those proposed, still manages to generate positive values (WTP) for its maintenance.

From the analysis of the correlations between traditional and innovative indicators, positive correlations are observed above all among the traditional indicators where a higher net revenue value is linked to a higher added value. From an economic point of view, this correlation is motivated by the fact that, where it is possible to generate income from wood products, a supply chain starts from the raw product up to 
the finished product, giving it a high added value.

A particular importance, always from an economic point of view, assumes a correlation between added value and the energy indicator, where being able to generate energy from wood products gives a high added value to the final forest product, which in this case is essentially represented by the woodchips. The added value provided by chips is related to the replacement effect between firewood and woodchips, taking into account that, in the current trend, woodchips are more preferable product than firewood [71].

The energy indicator is positively correlated with the net revenue produced, as it is able to take advantage of the possible additional revenues offered by the energy market.

The fact that the energy indicator is also related to high values among the workforce can lead to the conclusion that the importance of forest specialization is a strategic strength to be taken into consideration in the planning strategies. This thesis is further confirmed by the correlation that associates a high degree of workforce specialization with high quantities of firewood which can be traded annually.

There are also positive correlations that link important areas from an economic point of view (considering their added value, income and the energy from wood) with areas that have high recreational values: this link can be translated into WTP on the part of users of important areas, not only from a recreational (and therefore environmental) point of view, but also from an economic and social point of view. It is important to note that positive correlations observed between net revenues and recreation can be simply related to geographical reasons (i.e., district) and forest type: higher income from wood products is related to specific forest type (e.g., beech) which is highly appreciated for recreational activities.

As for the influence of the districts, the reason why Alpe di Catenaia shows the highest values for all the indicators can be explained by considering that this district and surrounding territory are historically suited to forest activities [13]. Indeed, higher values for workforce and trade in wood have also been observed in the Alto Tevere District. This is also related to the forest type characterizing these areas: in general, beech forests are usually more suited than other forest types, thus improving WTP values.

Economic indicators for added value and trade in wood are highly related to Turkey oak forests under conversion. This can be explained by the fact that the prevailing assortment, firewood, is especially common and easily tradable. Beech forest, managed both as traditional coppice and as conversion, is instead more related to a specialized workforce, which is a determining factor when the assortments are not exclusively concerned with firewood, but also include sawlogs. The net revenue indicator is related to Turkey oak coppice, which is able to provide revenues with a turnover of 25-30 years (scheduled over time), while the recreational aspects mainly affect forest with a prevalence of Holm oak and beech under conversion, which is optimal for their use, as they offer coverage throughout the year and a pleasant environment from an anaesthetic point of view, thereby being more suitable (especially second species) for recreational activities.

Other elements of interpretation concerned the specialization among the workforce involved in forestry activities, the quantity of wood that could potentially be marketed, and the opportunity to produce energy from wood products, as well as evaluating how wood products (woodchips, pellets etc.) represent competitive goods for firewood or even complementary goods.

The degree of appreciation expressed concerning the forest areas was also analysed, based on the WTP for the maintenance of forest areas and silvicultural options currently in place to benefit future generations.

This analysis could also provide information on the management of coppice, identifying trends in terms of both production and environmental aspects of forest areas. This evaluation is especially useful if the trends observed at the local level (in this case, in the districts of Tuscany) are compared with the trends of other regions and/or nations where coppices are present.

The set of indicators used allowed for the evaluation of the forms of management analysed, since it is able to cover three important points of view concerning sustainable forest management.

The first point is represented by the economic sphere analysed according to added value, net revenue and trade in wood. The social sphere has been examined by the forest workforce as a degree of specialization through which both the "quantity" of workers and the "quality" understood as the degree of training received by workers can make the forest sector, which is difficult to manage, competitive. The social aspects have been also addressed through the indicator relating to recreation and expressions of interest in the environment and more specifically in forest areas, directly involving the users of these areas in testing their level of interest.

Finally, the environmental sphere has been addressed through the indicator relating to energy from wood resources because it is important in the monitoring of alternative energies, as it allows for energy to be produced from wood resources with a lower level of $\mathrm{CO}_{2}$ emissions into the atmosphere, compared to fossil fuels.

However, this indicator can be also related to the other two aspects mentioned: it is certainly important from an economic point of view, as it is able to measure and quantify any revenues from wood products which, until recently, were regarded as waste products. It is also fundamental from a social point of view that the possible activation of a hypothetical forest-wood-energy chain involves different professional figures.

\section{Conclusions}

In numerous territorial contexts, there is a current tendency to realize a policy of converting coppice into high forest; but, in cases where coppice is locally important for social, traditional and economic reasons, it remains. Realistically, conversion is a labour-intensive process which is unlikely to be achieved without significant investment and the availability of subsidies. It therefore depends on the forest species considered and on the market for the obtainable wood assortments [8]. Coppice development is closely related to human efforts focused on establishing the sustainable management of forests with the minimal input of scarce resources, such as energy, capital and land. Sometimes, small-scale owners, particularly those who are farmers, produce firewood for personal consumption and local markets.

The actual forest management policies in Tuscany (which are highly related to the national ones) aim to support wood production without endangering the provision of other goods and services (Measure 8 and other sub-measures [72]).

The most frequent silvicultural treatments realized in regional property are conversion to high forest, performed mainly in coppices with good fertility and aged between 40 and 50 years. Coppice is essentially a system applied by forest owners for the production of firewood and small-to medium-sized material with rotations on a 25-40year basis.

In private ownership, traditional coppice utilization is more common, generally based on rotations of 25-40 years and managed in the framework of a rural economy according to traditional local practice.

Despite this, all three forms of management must be maintained because they guarantee high levels of sustainability in terms of income, employment and resources.

Obviously, the economic sustainability of coppice is strictly related to the presence of the firewood market. Given that natural evolution does not directly support wood production, traditional coppice and conversion to high forest promote wood production and other socioeconomic aspects, such as the harvested mass/increment ratio and roundwood, non-wood products, and net revenue. In particular, conversion to high forest, by combining high standing biomass and periodical harvestings, highlights the beneficial effects on sustainable wood 
production.

The points of weakness and strengths of each management option are summarized below.

Traditional coppice achieves high productivity in terms of wood growth and periodic utilization, which is mainly related to maximizing timber production with equally distributed incomes over time. At the same time, it presents a reduced growing stock which penalizes carbon sequestration.

Natural evolution increases the contribution to the carbon cycle, and to the health and vitality of the ecosystem, confirmed by the high growing stock and relative carbon stock. On the other hand, some of the socio-economic indicators considered have negative values. The absence of exploitation reduced the recreational value, led to negative revenues, and made impossible the recovery of wood residues for energy purposes.

The conversion to high forest combines high values of standing biomass and the possibility of wood exploitation by means of thinning. It also shows positive effects on environmental aspects (e.g., species diversity and energy from forest residues) and socio-economic aspects (e.g., net revenue), with particular reference to recreational ones.

Another important aspect is related to forest activities and integration within communities. Certainly, forestry activities play an important role in integrating immigrant labour in communities. Many companies operating in coppice forest employ foreign workers, especially from Eastern Europe. In some of the examined forest areas, this foreign workforce has contributed to reducing the risk of land abandonment. These workers have repopulated small villages at risk of depopulation, as well as reactivated the utilization and the sale of firewood.

Despite our efforts to analyse this argument, it is possible to observe a limitation of work (as mentioned in previous sections) related to a lack of forest statistics which are only available at a low level of detail: indeed, the indicator for workforce was not significant for the purpose of a comparison with the other indicators (the index was calculated using provincial and regional data). Future research could be more oriented towards producing data with a high level of detail. Indeed, the use of high-resolution data represents a new frontier in territorial planning $[54,72-77,80]$ which can enable the forest sector to become more competitive [79].

\section{Acknowledgements}

Thanks are due to Dr Francesca Giorgolo for her help with statistical analyses. The results that contributed to this work were made possible by funding from the LIFE Programme of the European Commission under Grant Agreement LIFE14 ENV/IT/000514 (LIFE FutureForCoppiceS, "Shaping future forestry for sustainable coppices in Southern Europe: the legacy of past management trials"). The authors also gratefully acknowledge the CREA Forestry Research Centre for the establishment and maintenance of the experimental trials.

\section{Appendix A. Supplementary data}

Supplementary data to this article can be found online at https://doi.org/10.1016/j.seps.2019.100732.

\section{Appendix}
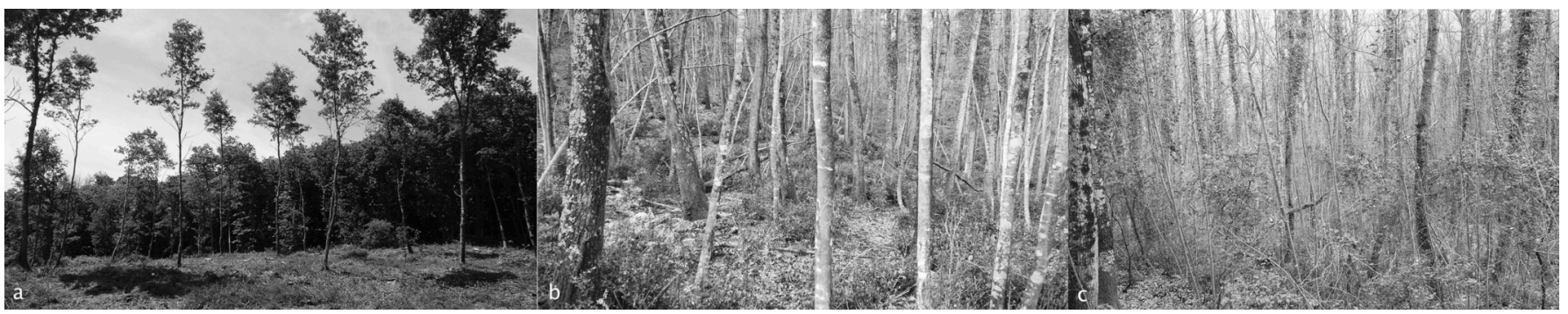

\section{References}

[1] FAO. Sustainable forest management. http://www.fao.org/forestry/sfm/en/; 2017, Accessed date: 9 May 2019

[2] De Meo I, Ferretti F, Frattegiani M, Lora C, Paletto A. Public participation GIS to support a bottomup approach in forest landscape planning. IForest 2013;6:347-52. https://doi.org/10.3832/ifor0917-006.

[3] Bruña-García X, Marey-Pérez MF. Public participation: a need of forest planning. IForest 2014;7:216-26. https://doi.org/10.3832/ifor0979-007.

[4] Bernetti I, Ciampi C, Fagarazzi C, Sacchelli S. I comparti forestale e di prima trasformazione del legno. In: ARSIAeditor. Stima della potenzialità Prod. delle agrienergie Toscana, Firenze. 2009. p. 43-70.

[5] Sacchelli S, Fagarazzi C, Bernetti I. Economic evaluation of forest biomass production in central Italy: a scenario assessment based on spatial analysis tool. Biomass Bioenergy 2013;53:1-10. https://doi.org/10.1016/j.biombioe.2012.11. 026.

[6] Schirpke U, Scolozzi R, De Marco C, Tappeiner U. Mapping beneficiaries of ecosystem services flows from Natura 2000 sites. Ecosyst Serv 2014;9:170-9. https:// doi.org/10.1016/j.ecoser.2014.06.003.

[7] Bajocco S, Ceccarelli T, Perini PL, Salvati L. Land-use trajectories and 'syndromes" of land degradation in northern Italy. Scienze Reg 2015:85-98. https://doi.org/10. 3280/SCRE2015-001005.

[8] Unrau A, Becker G, Spinelli R, Lazdina D, Magagnotti N, Nicolescu V, et al. Coppice forests in Europe. Uni Freiburg; 2018.

[9] IFNC Third National Forest Inventory. Inventario Nazionale delle Foreste e dei
Serbatoi Forestali di Carbonio. Ministero delle Politiche Agricole Alimentari e Forestali, Ispettorato Generale - Corpo Forestale dello Stato. Consiglio per la Ricerca e Sperimentazione in Agricoltura Unità di ricerca per il Monitoraggio e la Pianificazione Forestale (CRA-MPF). Report 2015. 2015.

[10] Piussi P. Il trattamento a ceduo di alcuni boschi toscani dal XVI al XX secolo. Dendronatura 1982;1.

[11] Piussi P, Zanzi Sulli A. Selvicoltura e storia forestale. Ann Ist Sper Selvic 1997; 46:25-42.

[12] Müllerová J, Hédl R, Szabó P. Coppice abandonment and its implications for species diversity in forest vegetation. Ecol Manag 2015;343:88-100. https://doi.org/10. 1016/J.FORECO.2015.02.003.

[13] Fabbio G, Cutini A. Coppice today: which management beyond definitions? For Riv Di Selvic Ed Ecol For 2017;14:257-74. https://doi.org/10.3832/efor2562-014.

[14] Ciancio O, Nocentini S. Il bosco ceduo. Firenze: Selvicoltura Assestamento Gestione; 2004.

[15] Corona P, Chirici G, Vannuccini M. Contributo conoscitivo sugli aspetti dendrometrici, auxometrici e gestionali dei cedui italiani. Accademia italiana di Scienze forestali. 2002. p. 73-124. bosco ceduo Ital., Firenze.

[16] Cantiani P, Amorini E, Piovosi M. Effetti dell'intensità della matricinatura sulla ricostituzione della copertura e sull'accrescimento dei polloni in cedui a prevalenza di cerro. Istituto sperimentale selvicoltura. 2006. p. 9-20. Selvic. sostenibile nei boschi cedui, Arezzo.

[17] Savini P, Cantiani P, Frattegiani M, Pedrazzoli M, Prieto D, Terradura M. Innovative coppice management in Umbria: coppice with groups of standards. Proc. IUFRO int. Conf. "Coppice for. Past, present futur., brno (Czech republic). 2015.

[18] Marchetti M, Motta M, Pettenella P, Sallustio S, Vacchiano V. Le foreste e il sistema 
foresta-legno in Italia: verso una nuova strategia per rispondere alle sfide interne e globali vol 15. 2018. p. 41. https://doi.org/10.3832/EFOR2796-015Http:// ForestaSisefOrg.

[19] Forest Europe. State of europe's forests. 20152015 http://foresteurope.org/stateeuropes-forests- 2015-report, Accessed date: 7 December 2018.

[20] Jolliffe IT. Principal component analysis. Springer; 2002.

[21] Toscana Regione. L'inventario forestale -Boschi e macchie di Toscana. www. regione.toscana.it/pro/indexsel.htm; 1998, Accessed date: 7 December 2018.

[22] ISTAT. IX Censimento industria e servizi e Censimento istituzioni non profit 2011. http://dati.istat.it/Index.aspx? DataSetCode=DCCN_VAAGSIPET; 2011, Accessed date: 7 December 2018.

[23] Bernetti I, Romano S. Economia delle risorse forestali. Napoli; 2007.

[24] Malagoli L, Bertoldo M. Estimo territoriale e ambientale. In: Aracneeditor. 2007. Roma.

[25] Michieli I, Michieli M. Trattato di Estimo. VII. Bologna; 2011.

[26] Gallerani V, Zanni G, Viaggi D. Manuale di estimo. second ed. 2011. Milano.

[27] ISTAT. VI Censimento generale dell'agricoltura. 2010.

[28] ISTAT. Classificazione delle attività economiche Ateco 2007. 2007https://www. istat.it/it/strumenti/definizioni-e-classificazioni/ateco-2007, Accessed date: 7 December 2018.

[29] Toscana Regione. Complessi del PAFR - terre di Toscana n.d. http://open.toscana. it/web/terre-di-toscana/complessi-del-pafr, Accessed date: 20 May 2019.

[30] ISTAT. Utilizzazioni legnose forestali per tipo di bosco e per destinazione. 2015http://agri.istat.it/jsp/dawinci.jsp?q = plF010000040000243200\&an = 2009\& ig $=1 \& c t=619 \& \mathrm{id}=68 \mathrm{~A} \% 7 \mathrm{C7A}$, Accessed date: 7 December 2018 .

[31] Bernetti I, Fagarazzi C, Romano S. Il mercato delle biomasse per scopi energetici in Toscana. In: Angeli Franco, editor. La Compet. dei Sist. Agric. Ital. Atti del XXXVI. Milano: Convegno Sidea; 1999.

[32] European Parliament. European policies on climate and energy towards 2020, 2030 and 2050 n.d. http://www.europarl.europa.eu/thinktank/en/document.html? reference $=$ IPOL_BRI\%282019\%29631047, Accessed date: 14 May 2019.

[33] iBionet. Intelligent bionenergy network. 2015http://www.ibionet.eu/, Accessed date: 7 December 2018.

[34] Fagarazzi C, Tirinnanzi A. Strumenti per lo sviluppo di filiere biomassa energia di qualità. Pisa. 2015.

[35] Viccaro M, Cozzi M, Caniani D, Masi S, Mancini I, Caivano M, et al. Wastewater reuse: an economic perspective to identify suitable Areas for poplar vegetation filter systems for energy production. Sustainability 2017;9:2161. https://doi.org/10. 3390/su9122161.

[36] Cozzi M, Viccaro M, Di Napoli F, Fagarazzi C, Tirinnanzi A, Romano S. A spatial analysis model to assess the feasibility of short rotation forestry fertigated with urban wastewater: basilicata region case study. Agric Water Manag 2015;159:185-96. https://doi.org/10.1016/J.AGWAT.2015.06.010.

[37] Walsh RG, Loomis JB, Gillman RA. Valuing option, existence and bequest demands for wilderness. Land Econ 1984;60:14-29.

[38] Mitchell RC, Carson RT. Using surveys to value public goods: the contingent valuation method. Washington. 1989.

[39] Foster V, Mourato S. Elicitation format and part-whole bias: do contingent valuation and contingent ranking give the same result? 1999.

[40] Bennett JW, Pearce DW, Turner RK. Economics of natural resources and the environment. Am J Agric Econ 1991;73:227. https://doi.org/10.2307/1242904.

[41] Pearce D, Turner K, Bateman I. Economia ambientale. Bologna. 2003.

[42] Anderson S, Harrison GW, Lau MI, Rutstrom EE. Elicitation using multiple price list formats. Exp Econ 2006;9:383-405. https://doi.org/10.1007/s10683-006-7055-6.

[43] Alphonce R, Alfnes F, Sharma A. Consumer vs. citizen willingness to pay for restaurant food safety. Food Policy 2014;49:160-6. https://doi.org/10.1016/j. foodpol.2014.06.009.

[44] Cameron TA, Huppert DD. OLS versus ML estimation of non-market resource values with payment card interval data. J Environ Econ Manag 1989;17:230-46. https:// doi.org/10.1016/0095-0696(89)90018-1.

[46] Tian X, Yu X, Holst R. Applying the payment card approach to estimate the WTP for green food in China. 2011.

[47] Cameron AC, Trivedi PK. Microeconometrics: methods and applications. New York. 2005.

[48] Riccioli F, Marone E, Boncinelli F, Tattoni C, Rocchini D, Fratini R. The recreational value of forests under different management systems. New Times 2019;50:345-60. https://doi.org/10.1007/s11056-018-9663-3.

[49] Mardia K, Kent J, Bibby J. Multivariate analysis. first ed. 1979. London.

[50] Raparelli E, Bajocco S, Mugnozza GS. The perception of biotechnology in agroforestry: the opinion of undergraduates and researchers. Land Use Policy 2017;66:364-73. https://doi.org/10.1016/J.LANDUSEPOL.2017.05.015.

[51] Vierikko K, Pellikka J, Hanski IK, Myllyviita T, Niemelä J, Vehkamäki S, et al Indicators of sustainable forestry: the association between wildlife species and forest structure in Finland. Ecol Indicat 2010;10:361-9. https://doi.org/10.1016/J. ECOLIND.2009.06.019.

[52] Mamipour S, Yahoo M, Jalalvandi S. An empirical analysis of the relationship between the environment, economy, and society: results of a PCA-VAR model for Iran. Ecol Indicat 2019;102:760-9. https://doi.org/10.1016/J.ECOLIND.2019.03.039.

[53] Liubachyna A, Bubbico A, Secco L, Pettenella D. Management goals and performance: clustering state forest management organizations in Europe with multivariate statistics. Forests 2017;8:1-23. https://doi.org/10.3390/f8120504.

[54] Riccioli F, Fratini R, Boncinelli F, El Asmar T, El Asmar J-PJP, Casini L. Spatial analysis of selected biodiversity features in protected areas: a case study in Tuscany region. Land Use Policy 2016;57:540-54. https://doi.org/10.1016/j.landusepol. 2016.06.023.

[55] James G, Witten D, Hastie T, Tibshirani R. An introduction to statistical learning with R. New York: Springer-Verlag; 2013.

[56] Seol A, Lee B, Chung J. Analysis of the seasonal characteristics of forest fires in South Korea using the multivariate analysis approach. J Res 2012;17:45-50. https://doi.org/10.1007/s10310-011-0263-8.

[57] Napier LFA, Aldrich C. An IsaMill ${ }^{\mathrm{TM}}$ soft sensor based on random forests and principal component analysis. IFAC-Pap OnLine 2017;50:1175-80. https://doi.org/ 10.1016/j.ifacol.2017.08.270.

[58] Lu H, Meng Y, Yan K, Gao Z. Kernel principal component analysis combining rotation forest method for linearly inseparable data. Cogn Syst Res 2019;53:111-22. https://doi.org/10.1016/j.cogsys.2018.01.006.

[59] Merlo M, Croitoru L. Valuing mediterranean forests: towards total economic value. Wallingford: CABI; 2005. https://doi.org/10.1079/9780851999975.0000.

[60] Fagarazzi C, Fratini R, Riccioli F. Sostenibilità economica delle utilizzazioni dei boschi cedui di quercia nel territorio toscano. Ann Ist Sper Selvic 2006;33:63-78.

[61] Bishop RC, Romano D. Environmental resource valuation vol 11. Boston, MA: Springer US; 1998. https://doi.org/10.1007/978-1-4615-5741-8.

[62] Romano D, Carbone F. La valutazione economica dei benefici ambientali: un confronto fra approcci non di mercato. Riv Econ Agrar 1993;48:19-62.

[63] Coppini M, Hermanin L. Restoration of selective beech coppices: a case study in the Apennines (Italy). Ecol Manag 2007;249:18-27. https://doi.org/10.1016/J. FORECO.2007.04.035.

[64] Ciancio O, Corona P, Lamonaca A, Portoghesi L, Travaglini D. Conversion of clearcut beech coppices into high forests with continuous cover: a case study in central Italy. Ecol Manag 2006;224:235-40. https://doi.org/10.1016/J.FORECO. 2005.12.045.

[65] Machado A. An index of naturalness. J Nat Conserv 2004;12:95-110. https://doi. org/10.1016/J.JNC.2003.12.002

[66] Lienhoop N, MacMillan D. Valuing wilderness in Iceland: estimation of WTA and WTP using the market stall approach to contingent valuation. Land Use Policy 2007;24:289-95. https://doi.org/10.1016/J.LANDUSEPOL.2005.07.001.

[67] Comber A, Carver S, Fritz S, McMorran R, Washtell J, Fisher P. Different methods, different wilds: evaluating alternative mappings of wildness using fuzzy MCE and Dempster-Shafer MCE. Comput Environ Urban Syst 2010;34:142-52. https://doi. org/10.1016/J.COMPENVURBSYS.2009.10.006.

[68] Orsi F, Geneletti D, Borsdorf A. Mapping wildness for protected area management: a methodological approach and application to the Dolomites UNESCO World Heritage Site (Italy). Landsc Urban Plan 2013;120:1-15. https://doi.org/10.1016/ J.LANDURBPLAN.2013.07.013.

[69] Carver SJ, Fritz S. Mapping wilderness: concepts, techniques and applications. Mapp wilderness concepts. Tech Appl 2016. https://doi.org/10.1007/978-94-0177399-7. 1-204.

[71] Spinelli R, Secknus M, Magagnotti N, Hartsough BR, Francescato V, Antonini E, et al. Linee guida per lo sviluppo di un modello di utilizzo del cippato forestale a fini energetici. [Trento: n.d].

[72] Toscana Regione, Psr. della Toscana: misure, sottomisure e operazioni - notizie Regione Toscana n.d. http://www.regione.toscana.it/-/psr-2014-2020-dellatoscana-misure-sottomisure-e-operazioni; 2014-2020, Accessed date: 20 May 2019.

[73] Zandersen M, Tol RSJ. A meta-analysis of forest recreation values in Europe. J For Econ 2009;15:109-30. https://doi.org/10.1016/J.JFE.2008.03.006.

[74] Baerenklau KA, González-Cabán A, Paez C, Chavez E. Spatial allocation of forest recreation value. J For Econ 2010;16:113-26. https://doi.org/10.1016/J.JFE.2009. 09.002.

[75] Bottalico F, Pesola L, Vizzarri M, Antonello L, Barbati A, Chirici G, et al. Modeling the influence of alternative forest management scenarios on wood production and carbon storage: a case study in the Mediterranean region. Environ Res 2016;144:72-87. https://doi.org/10.1016/j.envres.2015.10.025.

[76] Riccioli F, Gabbrielli E, Casini L, Marone E, El Asmar JPP, Fratini R. Geographical analysis of agro-environmental measures for reduction of chemical inputs in Tuscany. Nat Resour Res 2018. https://doi.org/10.1007/s11053-018-9398-z.

[77] Bernetti I, Sottini VA, Marinelli N, Marone E, Menghini S, Riccioli F, et al. Quantification of the total economic value of forest systems: spatial analysis application to the region of Tuscany ( Italy ). Aestimum 2013;201:29-65. Giugno.

[79] Alam MB, Shahi C, Pulkki R. Economic impact of enhanced forest inventory information and merchandizing yards in the forest product industry supply Chain. Socioecon Plann Sci 2014;48:189-97. https://doi.org/10.1016/j.seps.2014.06.002.

[80] Riccioli F, Boncinelli F, Fratini R, El Asmar J, Casini L. Geographical Relationship between Ungulates, Human Pressure and Territory. Applied Spatial Analysis and Policy 2018. https://doi.org/10.1007/s12061-018-9272-8. In press.

Francesco Riccioli is researcher in rural economics section at University of Pisa. His research sector mainly concerns agricultural and forest economics, spatial econometrics, GIS and automatic learning tools for Land use change analysis and analysis of agro-environmental policies.

Roberto Fratini is Associate Professor of Agricultural Economics and Rural Assessment at the Department of Agricultural, Food and Forestry Systems, University of Florence. His research sector mainly concerns forest policy and assessments

Enrico Marone is an associate professor in economics and rural assessment at the Department of Agricultural, Food and Forestry Systems, University of Florence. His research sector mainly concerns rural assessment and financial and statement analysis of rural enterprises;

Claudio Fagarazzi, is a professor of economics and rural assessment, the Department of Agricultural, Food and Forestry Systems, University of Florence. His research sector 
mainly concerns biomass management and environmental assessments in the forest sector.

Giorgio Brunialti is the Technical Director of TerraData environmetrics, a Spin Off company of the University of Siena (Italy). He is an expert in lichen biology and biodiversity. Research interests: environmental monitoring by means of indicator species.
Marco Calderisi is a member of the management board of TerraData environmetrics, a Spin Off company of the University of Siena (Italy). Expert in chemometrics. Research interests: statistical analysis of environmental monitoring data by applying a chemometrics. 